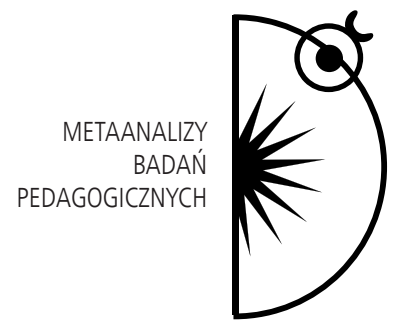

Marzenna Zaorska

\title{
Znaczenie badań nad zaburzeniami mowy - stan, perspektywy, wyzwania
}

DOI: http://dx.doi.org/10.12775/PBE.2013.020

\section{Dyskurs wprowadzający}

Logopedia polska jest jedną z tych subdyscyplin wiedzy, gdzie szczególnie wyraźnie, z niezwykłą konsekwencją i ogromną odpowiedzialnością etyczną przeplatają się wątki teoretyczno-praktyczne oraz stricte sub-, multi- i interdyscyplinarne. Znaczące jest również ukierunkowanie istoty naukowej i praktycznej eksploracji w obszarze logopedii egzemplifikujące się na zadaniach nadrzędnych, tzn. dbałości o prawidłową mowę oraz pożądany rozwój mowy, jak również kształtowanie umiejętności operowania (we wszelkich aspektach) słowem i szeroko ujętą komunikacją (w tym zasadniczo komunikacją językową) uwzględniającą piękno języka ojczystego. Dlatego taż istotnym celem logopedii polskiej, jako dziedziny teoretycznej i praktycznej, jest maksymalna koncentracja na credo języka narodowego, zaś przedmiotem zainteresowań - czynienie wszystkiego co możliwe, by uzyskać poziom sugerowanej poprawności mowy i wymowy oraz piękna mowy. Podane założenia koncepcyjne przyświecały nie tylko wybitnym bardziej współczesnym autorytetom zajmującym się zagadnieniami logopedii (np. Kaczmarkowi), ale także autorytetom tworzącym jej naro- 
dowe podstawy (chodzi tu m.in. o działalność Siestrzyńskiego, Ołtuszewskiego czy Dylewskiego) ${ }^{1}$.

Od początku swojego istnienia logopedia polska podkreślała konsensus korelacji pomiędzy zaburzeniami mowy a specyfiką psychospołecznego funkcjonowania osoby ludzkiej. Jest więc rzeczą oczywistą, że zaburzenia mowy, zależnie od ich rodzaju, etiologii, doświadczanych czy odczuwanych, niejednokrotnie subiektywnie, konsekwencji oraz możliwego zagrożenia nierealizacją osobistych planów życiowych, zawodowych, społecznych itd., komplikują rozwój człowieka, wywołują trudności w wypełnianiu ról (np. roli ucznia, pracownika, męża, żony, syna, córki), w nabywaniu wiedzy, spełnianiu siebie i percepcji siebie, w dochodzeniu do stanu transcendencji i satysfakcji z własnego życia w sferze socjokulturowej i duchowej.

Ponadto czasy współczesne unaoczniły inne, niespotykane w epokach minionych zadania wynikające $\mathrm{z}$ rozwoju cywilizacyjnego oraz nowych kryteriów decydujących o powodzeniu w życiu i uzyskiwaniu pozytywnej oceny ze strony innych ludzi. Ich istotą jest ukierunkowanie na osiąganie możliwie najwyższej jakości życia, na ogół w konstelacjach ekonomiczno-konsumpcyjnych. To wszystko powoduje, że współczesny człowiek powinien być wysoce dyspozycyjny, mobilny, sprawny, wykształcony, operującym językiem ojczystym w sposób wysoce poprawny, a nawet górnolotny. Dodatkowo powinien władać kilkoma językami obcymi, być wysportowany, odznaczać się miłą aparycją, nienagannym wyglądem fizycznym itd. Wskazanym preferencjom nie zawsze są $\mathrm{w}$ stanie sprostać osoby $\mathrm{z}$ różnego typu problemami rozwojowo-funkcjonalnymi, w tym osoby doświadczające wielozakresowych (nie tylko językowych i komunikacyjnych) konsekwencji zaburzeń mowy. Powstaje więc pytanie o skalę problemów obejmujących kwestie mowy i komunikacji językowej w populacji ludzkiej, a szczególnie w populacji dzieci i młodzieży. Pytanie posiadające charakter zarówno diagnostyczny, terapeutyczny, jak i profilaktyczny. I tu niestety dane na temat skali rozpowszechnienia analizowanych problemów są wysoce niepokojące. Okazuje się bowiem, że wśród dzieci objętych edukacją w oddziałach przedszkolnych zaburzenia/wady mowy mogą być obecne nawet u około $80 \%$. Na poziomie klas I-III obejmują przedział od 50 do $60-70 \%$; klas IV-VI 18-20\%². Dlatego wszelki dyskurs naukowy, badania naukowe oraz opracowane na ich podstawie rozwiązania adresowane do praktyki logopedycznej warto i należy przyjmować z należnym zainteresowaniem

\footnotetext{
${ }^{1}$ I. Styczek, Logopedia, PWN, Warszawa1983.

${ }^{2}$ Dane z praktyki własnej autorki artykułu.
} 
i powagą, bowiem mogą przyczynić się, jeśli nie do całkowitego usunięcia, to do poważnego ograniczenia wielorakich skutków zaburzeń mowy w obszarze indywidualnym i ogólnospołecznym, a także do poprawy jakości i efektywności działań terapeutycznych.

Stąd problematyka mowy w kontekście istoty, rozwoju i doskonalenia oraz mechanizmów funkcjonowania stanowi ważny i aktualny problem współczesnej logopedii - zarówno światowej, jak i polskiej. We współczesnym świecie szerokie kompetencje społeczne i indywidualne, sprawność we wszystkich możliwych sferach rozwoju są wyjątkowo ważne i znaczące. Szczególnego znaczenia nabierają także kwestie związane z mową artykułowaną (chodzi tu m.in. o poprawność fonetyczną, gramatyczną, leksykalną), kompetencjami komunikacyjnymi, umiejętnością podejmowania, realizacji i zamykania relacji interpersonalnych. Ponadto istniejące korelacje między rozwojem mowy a rozwojem psychicznym, emocjonalnym, społecznym, moralnym, jak również sukcesem edukacyjnym człowieka w okresie kształcenia i kolejno sukcesem rodzinnym, zawodowym, samorealizacją, autonomią osobową wymagają dyskusji na temat mowy w pozycji wyjątkowo uprzywilejowanej.

Z powyższych refleksji wynika więc zasadniczy wniosek, że wszelkie problemy/trudności z nabywaniem mowy, pozyskiwaniem kompetencji komunikacyjnych, operowaniem werbalnymi komponentami porozumiewania się mogą poważnie ograniczać, utrudniać, a czasami nawet uniemożliwiać egzystencję, identyfikację siebie przed sobą samym i identyfikację siebie wśród innych.

\section{Problematyka zaburzeń/wad mowy - dyskurs aktualistyczno-perspektywiczny}

Podejmując się próby wskazania ewentualnych i możliwych tendencji rozwojowych polskiej logopedii w korelacji teoretyczno-praktycznej, przede wszystkim należy wskazać wybrane źródła, czy inaczej ukierunkowania, poszukiwań intelektualnych ulokowanych zasadniczo w sferze partycypacji analityczno-syntetycznej.

Można określić trzy podstawowe strategie omawianego dyskursu w przełożeniu na trzy możliwe obszary. Pierwszym jest obszar logopedii stricte teoretycznej, drugim - logopedii teoretyczno-praktycznej, trzecim - logopedii praktycznej. Do każdego z wymienionych obszarów logiczne zdaje się przyporządkowanie określonych dyskursywnych problemów, aczkolwiek trudność pewną sprawia inter-, międzyobszarowy charakter niektórych z nich. 
W obszarze teoretycznym możemy mówić o wyzwaniach obejmujących kwestie strukturalne, historyczne i terminologiczno-klasyfikacyjne. W obszarze teoretyczno-praktycznym: profilaktyczno-diagnostyczno-terapeutyczne, prawno-organizacyjne, edukacyjno-specjalizacyjne i edukacyjno-promocyjne. Natomiast w obszarze praktycznym: materialno-działaniowe, współdziałaniowe i samoocenowo-etyczne.

Jeśli chodzi o pierwszy obszar i kwestie strukturalne, to warto zauważyć konieczność uporządkowania czy nawet rekonstrukcji struktury logopedii, szczególnie w aspekcie jej udoskonalenia, dostosowania do wymogów współczesności, osiągnięć nauki i praktyki, jak również dopełnienia o nowe elementy (np. logopedia biznesu, logopedia mediów). Do takich nowych elementów niewątpliwie należą zagadnienia komunikacji osób:

- z konkretnymi problemami rozwojowo-funkcjonalnymi, np. $\mathrm{z}$ autyzmem, niepełnosprawnościami sprzężonymi, złożonymi, wielozakresowymi, wielorakimi,

- z konkretnymi schorzeniami somatycznymi (np. z chorobą Perkinsona, Alzheimera) oraz zespołami uwarunkowanymi genetycznymi skorelowanymi z dysfunkcjami intelektualnymi (np. zespołem Downa, Wolfa-Hirshchorna, Pataua, Edwardsa, Cri du Chat i inne), skorelowanymi z dysfunkcjami słuchowo-wzrokowymi (tzw. zespoły słuchowo-wzrokowe, np. zespół Ushera, CHARGE, Marshalla), dysfunkcjami wzrokowymi (tzw. zespoły wzrokowe, np. zespół Lebara, Stadgardta), innymi zespołami uwarunkowanymi genetycznie, gdzie mamy do czynienia z wadami anatomicznymi, w tym związanymi z narządami mowy (np. sekwencja Pierre'a-Robina),

- doświadczających anatomicznych konsekwencji schorzeń nowotworowych, na tzw. onkologopedię (np. po laryngektomii),

- mających zaburzenia rozwojowe na tle wcześniactwa, embriopatii czy alkoholowego zespołu płodowego (FAS).

Kwestie historyczne natomiast postulują potrzebę realizacji badań historycznych nad dorobkiem światowej i polskiej logopedii oraz relacji i wzajemnych powiązań owego dorobku w odniesieniu do obopólnego wkładu, a także jego przeniesienia na ukierunkowanie logopedii współczesnej.

Kwestie terminologiczno-klasyfikacyjne z kolei zasadniczo egzemplifikują się w poszukiwaniu:

- konkretnej, jasnej, jednoznacznej interpretacji podstawowych terminów, którymi operuje logopedia teoretyczna (a zatem i praktyczna), szczególnie terminów takich jak: wada mowy, zaburzenie mowy, wada wymowy, 
zaburzenie wymowy, sprawność językowa, kompetencja/kompetencje komunikacyjna/komunikacyjne czy nawet afazja, dyslalia, dysglosja,

- możliwości dostosowania terminologii stosowanej w polskiej logopedii do terminologii światowej, a przede wszystkim terminologii stosowanej w państwach Unii Europejskiej (chodzi o tzw. unifikację),

- takich klasyfikacji wad/zaburzeń mowy/wymowy, które umożliwiałyby nie tylko uwzględnienie określonych parametrów klasyfikowania (np. etiologiczny, objawowy, rozwojowy, terapeutyczny), ale również służyły efektywnej i kompetentnej diagnostyce oraz trafionemu doborowi strategii terapeutyczno-stymulacyjnych.

Drugi obszar poszukiwań badawczych oraz naukowego dyskursu koncentruje się zarówno na działaniach teoretycznych, jak i praktycznych. Włącza, jak zasygnalizowano powyżej, zagadnienia profilaktyczno-diagnostyczno-terapeutyczne, prawno-organizacyjne, edukacyjno-specjalizacyjne i edukacyjno-promocyjne.

Zagadnienia profilaktyczno-diagnostyczno-terapeutyczne należy identyfikować jako:

- intensywne i celowo ukierunkowane działania na rzecz poszukiwania, opracowania oraz wdrażania nowych, nawet nowatorskich, rozwiązań i metod zapobiegania (profilaktyki) wszelakim problemom związanym z ewentualnością wystąpienia szeroko ujętych trudności komunikacyjnych, zapobiegania rozwojowi, pogłębianiu się problemów, które już są obecne, oraz zapobiegania rozwojowi zaawansowanej postaci problemów komunikacyjnych,

- analityczne i celowe poszukiwanie możliwości opracowania bardziej efektywnych narzędzi diagnostycznych pozwalających na identyfikację rzeczywistych potrzeb komunikacyjnych i rozwojowych diagnozowanego, na normatywne (ale nie tylko) rozpoznanie obecnych problemów, ale także wskazanie podstaw (zasobów wewnętrznych), na których można oprzeć postępowanie terapeutyczno-stymulacyjne,

- poszukiwanie, opracowanie, wdrażanie nowych/nowatorskich strategii/ /metod postępowania terapeutycznego, adekwatnych do obecnych problemów i indywidualnych potrzeb oraz możliwości podopiecznego, mających na uwadze jego dobro i prawo do autonomii osobowej i społecznej,

- refleksyjne i krytyczne podejście do metod terapii opracowanych $\mathrm{w}$ innych państwach i wprowadzanie na rynek polski tylko tych, które w zrealizowanych weryfikacyjnych eksperymentach zostaną praktycznie zewaluowane. 
Zagadnienia prawno-organizacyjne dotyczą starań, w tym naukowo-badawczych, skoncentrowanych na opracowaniu i prawnym unormowaniu statusu pomocy i terapii logopedycznej w strukturach systemu edukacji i opieki zdrowotnej. Wiąże się to $\mathrm{z}$ umocnieniem rangi pomocy logopedycznej nie tylko w możliwych zapisach prawnych, ale także w mentalnych nastawieniach społecznych wobec jej znaczenia, roli i wagi w ogólnym systemie specjalistycznego wsparcia. Ponadto z udoskonaleniem już istniejących rozwiązań prawnych. Chodzi tu m.in. o ostatnie rozporządzenia Ministra Edukacji Narodowej z 2010 r., a konkretnie o Rozporządzenie Ministra Edukacji dnia 17 listopada 2010 r. w sprawie zasad udzielania i organizacji pomocy psychologiczno-pedagogicznej w publicznych przedszkolach, szkołach i placówkach ${ }^{3}$ i Rozporządzenie Ministra Edukacji Narodowej dnia 17 listopada 2010 r. w sprawie warunków organizowania kształcenia, wychowania i opieki dla dzieci i młodzieży niepełnosprawnych oraz niedostosowanych społecznie w przedszkolach, szkołach i oddziałach ogólnodostępnych i integracyjnych ${ }^{4}$.

W pierwszym z wymienionych rozporządzeń terapia logopedyczna stanowi integralny element ogólnego systemu pomocy psychologiczno-pedagogicznej udzielanej uczniom na terenie szkoły, a dodatkowo element zajęć specjalistycznych (np. wraz z zajęciami korekcyjno-kompensacyjnymi, socjoterapeutycznymi, innymi zajęciami o charakterze terapeutycznym). Wymagany czas trwania zajęć logopedycznych to godzina zegarowa. Podano formy pomocy logopedycznej (podobnie jak i innych form pomocy psychologiczno-pedagogicznej): zajęcia specjalistyczne, porady i konsultacje. Zajęcia logopedyczne organizowane są dla uczniów z zaburzeniami mowy, „które powodują zaburzenia komunikacji językowej oraz utrudniają naukę". Liczba uczestników zajęć powinna wynosić do 4 osób. Należy także powołać zespoł do spraw pomocy psychologiczno-pedagogicznej, np. w oddziałach przedszkolnych. W pracach takiego zespołu mają prawo uczestniczyć rodzice oraz specjaliści (szczególnie lekarz, psycholog, pedagog). Posiedzenia zespołu są zwoływane w miarę potrzeb. Zespół opracowuje formy i plan działań wspierających (liczbę godzin), wskazuje metody pracy, zakres dostosowania wymagań edukacyjnych

\footnotetext{
${ }^{3}$ Rozporządzenie Ministra Edukacji Narodowej z dnia 17 listopada 2010 r. w sprawie zasad udzielania i organizacji pomocy psychologiczno-pedagogicznej w publicznych przedszkolach, szkołach i placówkach, Dz. U. Nr 228.

${ }^{4}$ Rozporządzenie Ministra Edukacji Narodowej z dnia 17 listopada 2010 r. w sprawie warunków organizowania kształcenia, wychowania i opieki dla dzieci i młodzieży niepełnosprawnych oraz niedostosowanych społecznie w przedszkolach, szkołach i oddziałach ogólnodostępnych i integracyjnych, Dz.U. Nr 228.
} 
wynikających z programu nauczania do indywidualnych potrzeb rozwojowych i edukacyjnych oraz możliwości psychofizycznych ucznia. Uwzględniono także działania wspierające rodziców ucznia oraz zakres współdziałania z poradniami psychologiczno-pedagogicznymi, w tym poradniami specjalistycznymi, placówkami doskonalenia nauczycieli, organizacjami pozarządowymi oraz innymi instytucjami działającymi na rzecz rodziny, dzieci i młodzieży. Zespół dokonuje oceny efektywności pomocy psychologiczno-pedagogicznej i efektywności realizowanych zajęć specjalistycznych. Zakłada także kartę indywidualnych potrzeb ucznia (nie zakłada karty uczniowi z orzeczeniem o potrzebie kształcenia specjalnego). Po zakończeniu udzielania pomocy psychologiczno-pedagogicznej uczeń otrzymuje oryginał karty (kopia pozostaje w placówce). Do końca marca należy dokonać oceny potrzeb w zakresie pomocy psychologiczno-pedagogicznej na kolejny rok szkolny. Do 30 kwietnia dyrektor placówki, na podstawie propozycji zespołu, ustala zakres oraz wymiar godzinowy pomocy psychologiczno-pedagogicznej na kolejny rok szkolny. Niezwłocznie po zatwierdzeniu przez organy prowadzące arkuszy organizacji szkół na kolejny rok szkolny dyrektorzy informują na piśmie rodziców ucznia albo pełnoletniego ucznia o ustalonych formach pomocy, sposobach i okresach udzielania pomocy oraz wymiarze godzin poszczególnych form pomocy w roku szkolnym. W terminie do 30 września zespół opracowuje dla uczniów plany działań wspierających realizowanych w danym roku szkolnym.

W analizowanym rozporządzeniu określono zadania logopedy w przedszkolu, szkole, placówce:

- prowadzenie badań wstępnych w celu ustalenia stanu mowy uczniów, w tym mowy głośnej i pisma,

- diagnozowanie logopedyczne oraz, odpowiednio do jego wyników, udzielanie pomocy logopedycznej poszczególnym uczniom z trudnościami w uczeniu się, we współpracy z nauczycielami prowadzącymi zajęcia z uczniem,

- prowadzenie terapii logopedycznej indywidualnej i grupowej dla uczniów, w zależności od rozpoznanych potrzeb,

- podejmowanie działań profilaktycznych zapobiegających powstawaniu zaburzeń komunikacji językowej, w tym współpraca z najbliższym środowiskiem ucznia.

Można jednak zauważyć poważne utrudnienia związane z faktyczną realizacją zadań adresowanych do pomocy logopedycznej w świetle obowiązującego rozporządzenia, np.: na zajęcia logopedyczne w oddziale przedszkolnym na ogół (zależnie od możliwości finansowych konkretnych gmin i powiatów) 
przeznacza się 1 godzinę zegarową $\mathrm{w}$ tygodniu na jedną grupę, co przy dwóch grupach daje $2 / 20$ etatu. Poza tym logopeda pracujący w danych oddziałach zobowiązany jest do realizacji 7 tzw. godzin karcianych w ciągu roku szkolnego. W projektach unijnych obowiązuje zapis o minimalnej liczbie godzin przeznaczanych na zajęcia specjalistyczne i wynosi on minimum 30 godzin zegarowych (aczkolwiek w analizowanym rozporządzeniu takiej informacji nie ma). W oddziałach przedszkolnych rok szkolny obejmuje zasadniczo 32 tygodnie i 1 godzinę zegarową tygodniowo, tzn. wyniesie 32 godziny zegarowe w ciągu roku szkolnego. Oznacza to, że przy wymaganej minimalnej liczbie godzin terapii logopedycznej na jednego ucznia - 30 godzin, możliwa liczba uczniów objętych terapią indywidualną wyniesie 1,06, a możliwa liczba uczniów korzystających z zajęć logopedycznych w grupach 3-osobowych - 3,18. Potrzeby logopedyczne w oddziałach przedszkolnych (na podstawie doświadczeń praktyki) obejmują około $80 \%$. W grupie 25 dzieci pomoc logopedyczna może być wobec powyższego udzielona $12,7 \%$ uczniów.

Jeśli chodzi o etat logopedy, to przeważnie (chociaż, jak sygnalizowano wyżej, decyzje w danym względzie są uzależnione od majętności gmin i powiatów) czas pracy logopedy wynosi 20 godzin zegarowych tygodniowo oraz 2 godziny zegarowe tygodniowo, tzw. godziny karciane (na dodatkowe zajęcia, np. z zakresu logorytmiki). W czasie roku szkolnego trwającego 32 tygodnie i 20-godzinnym tygodniu pracy logopeda jest w stanie zrealizować 640 godzin zajęć terapeutycznych (przy założeniu, że nie realizuje żadnych działań diagnostycznych). Daje to, przy wymogu minimum 30 godzin zajęć na jednego ucznia, 21,3 ucznia, jeśli chodzi o możliwą liczbę uczniów zakwalifikowanych na zajęcia indywidualne, a przy zajęciach grupowych w grupach 3-osobowych 64 uczniów. Na podstawie danych kalkulacji można wskazać, że możliwy do objęcia terapią logopedyczną grupową w szkole liczącej 1000 uczniów odsetek dzieci wyniesie 6,4\%; w szkole liczącej 800 uczniów - 8\%; w szkole liczącej 600 uczniów - 10,7\%; średnie wskaźniki potrzeb logopedycznych w szkołach ogólnodostępnych (na podstawie danych z praktyki logopedycznej) to minimum $18 \%$.

W obszarze drugim - koncentrującym się na dylematach praktyczno-teoretycznych, wskazano również kwestie edukacyjno-specjalizacyjne. Związane są one z zagadnieniem organizacji i realizacji działalności uczelni wyższych (państwowych i niepaństwowych) na rzecz przygotowania do pracy logopedów wyposażonych w szeroki zasób wiedzy teoretycznej i faktyczne umiejętności praktyczne, czyli przygotowania specjalistów dysponujących kompetencjami powalającymi w połączeniu z predyspozycjami własnymi, szczególnie osobo- 
wościowymi i dotyczącymi poziomu i prawidłowości operowania językiem, na bycie profesjonalistą $\mathrm{w}$ danym obszarze działalności terapeutycznej. Opisane założenie wymaga więc nie tylko weryfikacji istniejących planów studiów wyższych (pierwszego i drugiego stopnia), gdzie kształceni są logopedzi, ale także standaryzacji ukierunkowanej na selekcję kandydatów na takie studia zarówno pod względem szeroko ujętej poprawności komunikacyjnej, jak i predyspozycji osobowych. Ponadto analizowane kwestie mają też na uwadze edukację specjalistyczną, a właściwie specjalizacyjną osób, które zawód logopedy już zdobyły. Chodzi tu o ukierunkowanie kształcenia logopedów po kształceniu ogólnologopedycznym na kształcenie wysoce specjalistyczne w ramach ważnych, znaczących i korespondujących z potrzebami konkretnych populacji beneficjentów wsparcie logopedyczne (np. w ramach surdologopedii, neurologopedii, balbutologopedii czy wymienionych w obszarze pierwszym innych adresatów pomocy logopedycznej).

Następną kwestią uwzględnioną w drugim obszarze naukowo-badawczych poszukiwań współczesnej logopedii w Polsce są działania edukacyjno-promocyjne. Zasadniczo posiadają one wymiar stricte profilaktyczny, bowiem postulują określenie strategii edukacji społeczeństwa, strategii informacyjnych promujących problematykę logopedyczną wśród różnych grup społecznych celem wyczulenia na piękno języka, na potrzebę poprawnej mowy, rolę mowy w życiu ludzkim i ewentualne problemy wynikające z zaburzeń/wad mowy, jak również na ukształtowanie dystansu wobec aktualnych zjawisk cywilizacyjnych: minimalizacja osobistych relacji pomiędzy ludźmi, ograniczanie ilości i czasu ich trwania, telegraficzny, skrótowy sposób przekazywania komunikatów we współczesnych mediach oraz wprowadzanie do słownictwa, jako obowiązujących, zwrotów i określeń z języków obcych, niekorespondujących z naszym, polskim dorobkiem historyczno-kulturowym i istotą języka polskiego.

W trzecim obszarze naukowo-badawczych poszukiwań współczesnej logopedii w Polsce znajdują się kwestie materialno-działaniowe, współdziałaniowe i samoocenowo-etyczne.

Kwestie materialno-działaniowe należy rozumieć jako te, które dążą do zidentyfikowania wpływu wyposażenia i organizacji tzw. warsztatu pracy logopedy na efektywność podejmowanych działan diagnostyczno-terapeutycznych. Dotyczą rozwiązań odniesionych do organizacji pracy logopedy, wyposażenia gabinetu w specjalistyczny sprzęt i pomoce dydaktyczne, nawet umiejscowienia gabinetu w placówce, w której pracuje logopeda, i estetyki sali, gdzie dane zajęcia są realizowane. 
Kwestie współdziałaniowe z kolei dotyczą eksploracji naukowych poszukujących najbardziej efektywnych rozwiązań, zasad i form współpracy logopedy z innymi instytucjami, organizacjami i specjalistami zajmującymi się edukacją, wspomaganiem rozwoju i terapią osób doświadczających problemów rozwojowo-funkcjonalnych obejmujących różne grupy wiekowe (nie tylko dzieci i młodzież, ale również osoby dorosłe), nauczycielami i środowiskiem rodzinnym takich osób.

Niezwykle trudne do poznania, ale też wymagające wnikliwych dociekań badawczych, a zatem relatywnych rozwiązań praktycznych, są kwestie samoocenowo-etyczne. Oznaczają nie tylko rozpoznanie kandydatów do zawodu logopedy pod względem cech osobowych/osobowościowych, ale także określenie możliwości kształtowania i rozwoju cech pożądanych, konstruowanych na bazie wysokiego morale, wysokiej, prawdziwej, uwzględniającej uniwersalne wartości etyki zawodowej i etyki własnej/własnej aksjologii, pozwalającej na ocenę siebie jako człowieka i specjalisty w powiązaniu z realizowanymi działaniami. To też kwestia dotycząca problemu samorozwoju, samodoskonalenia i działania promującego w pierwszej kolejności dobro podopiecznego, w tym działania dalekiego od manipulacji ukrywających intencje zaspokojenia indywidualnych ambicji, autopromocję i realizację prywatnych interesów, materialnych, uznaniowych czy awansowych.

\section{Podsumowanie}

W podsumowaniu warto odpowiedzieć na pytanie o znaczenie, stan i perspektywy badań nad zaburzeniami mowy. Znaczenie badań naukowych nad dylematem zaburzeń/wad mowy można analizować oraz lokować, o czym była już mowa powyżej, w powiązaniu z rozwojem osoby ludzkiej, zarówno w kontekście profilaktyki, jak i najbardziej efektywnej terapii możliwych problemów w obszarze komunikacji, i globalnie w obszarze rozwoju ogólnego. Z kolei aktualny dyskurs nad stanem badań nad zagadnieniami związanymi z problematyką mowy należy uznać za zadowalający, aczkolwiek istnieją określone braki szczególnie w odniesieniu do problemów bardziej złożonych lub tych, które z powodu rozwoju nauki zaistniały stosunkowo niedawno. Natomiast perspektywy badawcze wiążą się z czujnym podążaniem za rozwojem współczesnej cywilizacji i natychmiastową reakcją z jednej strony na nowe zagadnienia, a z drugiej strony - z maksymalizacją efektywności i minimalizacją czasu terapii logopedycznej. Zarówno stan, jak perspektywy badań naukowych w logopedii są jednoznacznie uzależnione od ludzi, którzy zawód logopedy realizują, od 
ich powołania, predyspozycji, kompetencji i w konsekwencji profesjonalizmu, który to profesjonalizm owe powołanie, predyspozycje i kompetencje tworzy, krystalizuje i ściśle cementuje.

\section{Bibliografia}

Rozporządzenie Ministra Edukacji Narodowej z dnia 17 listopada 2010 r. w sprawie zasad udzielania i organizacji pomocy psychologiczno-pedagogicznej w publicznych przedszkolach, szkołach i placówkach, Dz.U. Nr 228.

Rozporządzenie Ministra Edukacji Narodowej z dnia 17 listopada 2010 r. w sprawie warunków organizowania kształcenia, wychowania i opieki dla dzieci i młodzieży niepełnosprawnych oraz niedostosowanych społecznie w przedszkolach, szkołach i oddziałach ogólnodostępnych i integracyjnych, Dz.U. Nr 228.

Styczek I. (1983), Logopedia, PWN, Warszawa.

\section{The meaning of studies on speech disorders - the present state, future perspectives, challenges}

\section{Summary}

The article presents reflections on the subject of previous aim of scientific and practical searches that are present in polish speech therapy with an annotation about it's historical work and experience, also with the description of the present state. Additionally the article tries to highlight the new and possible areas of scientific and practical analysis in the context of future.

Keywords: logopedics, diagnosis, therapy, speech therapy, prophylactics, logopedic therapy, logopedic prophylactics. 